\title{
MERCANTILIST ORIGINS OF CAPITALISM AND ITS LEGACIES:FROM BIRTH TO DECLINE OF WESTERN HEGEMONY
}

\author{
Kari Polanyi Levitt*
}

\section{Resumen}

En este artículo examinamos el capitalismo desde su origen mercantilista en Europa hasta la financiarización de las economías occidentales y el desenvolvimiento de la hegemonía anglo-americana. Existen características históricas y continuas: la dominación de los centros de capital sobre la producción en la periferia, especialmente en aquellas economías basadas en la producción de materias primas y la subcontratación de fuerza de trabajo por corporaciones multinacionales. No obstante, la subordinación de la producción a los grandes conglomerados del capital comercial y financiero ha penetrado el corazón occidental del capitalismo. La financiarización rampante está destruyendo la capacidad productiva de estos países y ha precipitado la crisis más severa desde 1930. El estilo depredador del capitalismo actual está más preocupado con la acumulación de riqueza, la manipulación financiera, la privatización de bienes públicos y el arrebato de la tierra a la población. En este sentido, podemos ver el capitalismo occidental contemporáneo como un regreso a sus origines comerciales mercantalistas.

Palabras clave: capitalismo, desarrollo, imperialismo, hegemonía occidental, crisis financiera.

* Emerita Professor of Economics McGill University. 


\section{Abstract}

In this paper we trace capitalism from its origins in European expansion by commerce and conquest to the financialization of Western economies and the unraveling of Anglo-American hegemony. We emphasize continuities in the domination of metropolitan capital over peripheral production from the slave plantations to the outsourcing of manufacturing to cheap labor locations by multinational corporations. But the subordination of production to powerful agglomerations of commercial and financial capital has now penetrated the Western heartlands of capitalism, where rampant financialization is destroying productive capacity and has precipitated the most serious crisis since the 1930s. This predatory style of capitalism is more concerned with the accumulation of wealth by financial manipulation, mergers and acquisitions, privatization of public assets, and dispossession of peoples in distant lands than with investment in productive capacity. In this sense we may regard contemporary Western capitalism as a return to its mercantile commercial origins.

Keywords: capitalism, development, imperialism, Western Hegemony, financial crisis. 
$\mathrm{s}$ in the mercantilist era preceding the achievements of
industrial capitalism with regards to an extraordinary in-
crease in the production of material goods and services, the instruments of Western hegemony are increasingly financial and military. ${ }^{1}$

In the United States, the contribution of manufacturing activity to GDP has declined to $12 \%$, some $80 \%$ of which is directly or indirectly driven by defense expenditures. ${ }^{2}$ Deindustrialization in Britain has proceeded even more rapidly and dependence on income generated by financial services is more extreme than any other major country. In this regard, and also with respect to the appropriation of land and mineral resources, contemporary capitalism shares characteristics with its origins in mercantile commerce and conquest.

The mercantilism of the era preceding the industrial revolution was characterized by a historically specific symbiotic relationship between the national sovereign and the merchant class in the accumulation of territory and wealth. The sovereign granted monopoly rights to merchant companies to establish exclusivist relations with foreign rulers, engage in trade, raise armies, and dispense justice. The proceeds from merchant trade enabled the sovereign to subdue internal enemies, finance navies, and wage wars with rival nations.

The dominance of large metropolitan commercial enterprise over distant sources of supply can most clearly be seen in the days of mercantilism, but continued in the imperialist division of labor between colonies and industrial centers. The companies are typically large and powerful business enterprises compared with the multitude of producers whose access to metropolitan markets they control. As few buyers from many sellers, they are in a position to establish the ruling market price and extract monopsony

1. This article is a revised and extended text of a lecture delivered to the summer school of Critical Development Studies, Universidad Autónoma de Zacatecas, Mexico, August, 2009.

2. The figure dates from 1990, but is likely to have increased rather than diminished since that time. http://mondediplo.com/2008/02/05military, Chalmers Johnson. 
rents from producers. As powerful sellers to many buyers, they are similarly positioned to extract monopoly rents from consumers. Thus the companies who control the channels of distribution are in a position to capture the major share of the surplus generated by producers. Indeed, some of the largest trans-national corporations of our times often do not engage directly in production.

In Silent Surrender (Levitt, 1970; 2005) we suggested that the chartered companies of the old mercantilism were the forerunners of the transnational corporations of a new mercantilism, with the difference $t$ in the laties also engaged in large-scale manufacturing both in home and host countries. In the forty years that have passed, information and communications technology has diversified the geographical spread of the locations of production of ever -fewer, -ever larger, and more powerful corporations; global control over sources of supply and markets is increasingly exercised by proprietary technology, patents, licensing, franchising, branding and trademarks. Examples abound, Wal-Mart and Monsanto are perhaps the most notorious examples of sophisticated practitioners of the creation of rents by monopsony and monopoly.

Unlike the chartered companies of the old mercantilism that operated at the will and with the benediction of the sovereign, the transnational corporations of the new mercantilism have penetrated the corridors of power in the West and effectively control the political process. Governments are hostage to the judgment of markets. The failure of US and British governments to limit the power of financial capital in the wake of the 2008 crisis has demonstrated the degree to which the democratic process has been undermined. This contrasts with the New Deal measures implemented in the US in the 1930s. Global capital has emerged as powerful as ever and now threatens the viability of the Eurozone.

Prior to the progressive liberalization of capital, commercial banks performed an essential function in channeling the savings of households to extend credit to business and industry; they were not permitted to trade in foreign exchange, issue insurance, or assume the functions of investment banks. In Canada, there was a le- 
gal ceiling of $6 \%$ on interest permitted. In the classic model of industrial capitalism, M-C-M', as described by Marx, an initial outlay of money capital (M) purchases commodities - raw materials and labor power- (C) to produce a product for sale at a value (M') exceeding initial outlay of capital. In early English industrial capitalism when Marx formulated this model, the source of profit was surplus value created in the sphere of production by the exploitation of labor. Marx shared the general assumption of competitive markets and the sphere of circulation $w$ un less important in his model. The outrageous profits made by financial industries before and also after the crisis of 2008 may be depicted as M-M', short-circuiting the process of production altogether. It is a regression of capitalism to its mercantile origins in commerce and dispossession.

It is important here to state that the profits of non-financial transnational corporations can no longer be usefully depicted by Marx's formula, with its emphasis solely on the employment of labor in the "sphere of production». Technological change has greatly reduced the role of labor and the inputs of raw material to production. Contemporary capitalism does not require an ever-expanding supply of labor; poor people in poor countries are redundant to this model as producers and consumers. The «sphere of circulation» has become an important source of the creation of rents by proprietary control of technology and marketing. The control of large corporations over channels of distribution is also reminiscent of the companies in the Mercantilist Era, and while this has always been a characteristic of peripheral capitalism, it is now a general feature of Western corporate capitalism within the metropole.

Two hundred years (1780-1980) of the application of technology to industry, with ever-increasing employment and reinvestment of profit, transformed agricultural societies into industrial civilization in Europe and its diasporas. Europe gave birth to industrial capitalism but the European world has exhausted its historic role in the application of science and technology to the production of socially useful goods and services. Creativity in financial operations and trading in existing assets for short-term profit has replaced creativity in 
production and long-term investment in infrastructure to meet the challenges of a rapidly changing world. The final outcome of the financialization initiated by the United States and Britain, together with their unwinnable military adventures in Western Asia, promise to hasten the end of Anglo-American hegemony. The growing points of the world economy are shifting from North and West to South and East. The Eurocentric belief that the West knows best is widely discredited. Asia is making a slow return to its historic place in the world economy and major Latin American countries have adopted a variety of policies to secure a greater measure of equity and social justice in the distribution of national wealth.

\section{MERCANTILISM AND ITS CONTINUITIES}

Eurocentrism has exaggerated the relative economic development of Europe compared with that of Asia prior to the advent of industrial capitalism; the scale of manufacturing in India and China greatly exceeded that of Europe, and European trade-goods were inferior to the desirability of Asian silk and cotton textiles and porcelain, hence the importance of Europe's access to America's gold and silver to cover its imbalance of trade with the East.

There was no substantial technological progress in the era of mercantilism. There was no difference between major regions of Eurasia and the Americas in 1500; by 1700 GDP per capita in China, India, Eastern Europe and the Americas was still approximately equal, although Britain and Western Europe were by then somewhat higher (Madison, 2006). ${ }^{3}$ The Brazilian economist and economic historian Celso Furtado (1983: 29-33) reminds us that the large surplus drained into Western regions of Europe from

3. Maddison is used for all «GDP as a share of world production» and «GDP per capita» data. He uses 1990 Geary-Khamis Dollars with Purchasing Power Parity. A full explanation of Maddison's background methodology and reasoning can be found here: http://www.ggdc.net/maddison/Historical_Statistics/BackgroundHistoricalStatistics_03-2010.pdf 
overseas expansion stimulated economic development but was not invested in significant improvement in the means of production prior to the bourgeois revolution. Merchant capital was reinvested in domestic and overseas trade, the production of trade goods, and in finance extended to the courts of kings and princs. It was not by superiority in production, but by superiority in commerce and conquest that primitive accumulation transferred resources from the non-European world to European metropoles.

Long before the Ottoman Turks captured Constantinople (1453) and cut the last trade routes from the Mediterranean to Asia, the action had shifted to the Atlantic Seaboard. The first countries to sail around Africa and into the China Sea were Portugal and Holland, soon joined by the English. They engaged in trade for gold, slaves and ivory on the coast of Africa, and established trading posts from the Cape to Ceylon (now Sri Lanka) to the Malacca Straits, and the China Sea as far as Japan; initially they were traders of little significance or importance within a dense network of trade.

Of all the nations of the Atlantic seaboard, the Dutch were supreme in the arts of overseas commerce. They had long controlled the Baltic trade and in the $17^{\text {th }}$ century extended their commercial empire to a monopoly over the spice islands of the Indonesian archipelago, where they remained as the colonial power of the Dutch East Indies into the 1950s. It may seem strange today that spices like peppers, nutmeg, cardamom and cinnamon were so highly valued, but they were used to preserve food in the days before refrigeration. The Dutch East India Company, established in 1602 with a monopoly from the Cape to the Straits of Magellan in South America, had sales and profits ten times those of the English East India Company, established in 1599. The success of the Dutch commercial empire was impressive, but the Dutch could not compete with England and France in the Atlantic region because their population was too small for effective naval warfare or colonial settlement. Accumulated money wealth was invested in finance, and Amsterdam became the financial center of Europe, hosting its first stock exchange. The first recorded speculative bubble was 
the Tulip-mania of 1637, when - at their peak- Dutch Tulip contracts sold for 10 times the annual income of a skilled craftsman (Mackay, 1841). Wealthy patrons supported a cultural renaissance in the Netherlands as hegemony passed from Holland to England. Giovanni Arrighi (1994) observed that the decline of successive hegemonic powers, beginning with Genoa, was accompanied by the financialization of accumulated wealth.

\section{OVERSEAS ECONOMIES OF EUROPE IN THE ATLANTIC REGION}

The accumulation of capital from trade with Asia was substantial, but modest compared with the benefits that accrued to Europe from its westward expansion. With the voyages of Columbus, the small nation states of the Atlantic seaboard extended the effective territorial space of Western Europe to embrace all of the Americas. The projection of European economic power with the establishment of colonies of conquest, exploitation and settlement in the Americas would profoundly affect the development of capitalism on a world scale.

\section{Colonies of Conquest}

The majority of the population of the Americas did not survive the arrival of Columbus in 1492. From Mexico to Bolivia, Aztec and Inca civilizations were destroyed. Treasure of gold and silver was looted and much of the surviving population enslaved to work the silver mines for the benefit of the Conquistadors and the Spanish Crwn. The marginalization of indigenous peoples continues in Latin America. The legacy of ethnic and class cleavages is manifested in inequality of incomes and assets surpassing those in Africa or Asia.

The gold and silver shipped to Spain monetized feudal obligations and quickened commerce and economic development throughout Western Europe. The principal beneficiaries were Italian, German, Dutch, and other merchants who came to trade their wares in Spain 
and Portugal for silver. The lavish expenditures of the Spanish court and the finance extended to allied monarchs and princes impoverished the country. It was an example of what later became known as the Dutch disease, afflicting countries with easy access to hard currencies spent on excessive imports to the detriment of domestic industries.

\section{Colonies of Exploitation}

On the coasts of the Americas and the islands of the Caribbean, Europeans competed in the establishment of colonies of exploitation created for the single purpose of producing a valuable commodity for profitable sale in the metropole by the exploitation of slave labor. Between ten and fifteen million slaves were transported across the Atlantic from the coasts of Africa. It was a hazardous passage, many perished. An estimated five million were reported to have landed in Northeast Brazil; upward of two million in the Spanish coastal regions and islands; between one-and-a-half and two million in the British islands of the Caribbean, and similar numbers in the French islands; half a million in the Southern States of North America; and smaller numbers in the Dutch, French, and British Guyanas. Throughout more than two centuries of the African slave trade, the plantations of the New World were the principal market, supplied by Portuguese, Dutch, and English slave traders. On the islands, where cultivation was extended to the limit of available land, the labor regime was so harsh that a slave landed in Jamaica had an average life expectancy of only eight years. People were worked to death. The population could not reproduce itself and new supplies of slaves were constantly required. On the continent of North America, with an open land frontier, the slave population increased by natural reproduction, giving rise to an African-American population now in the tens of millions. Similarly, by mid $19^{\text {th }}$ century, the majority of the Brazilian population was of African descent. Slavery was not abolished in Brazil until 1888, but by that time only $4 \%$ of the population was still unfree. 
Slave plantations were enormously profitable; they played a significant role in European economic development-a role in many ways as important as the exploitation of the silver mines of South America. In France, St. Domingue (now Haiti) was known as the Pearl of the Antilles; for England, Jamaica played a similar role. The establishment by metropolitan capital of plantations constituted the first investment in productive enterprise in the overseas economies of their respective metropoles. Plantation capitalism was the original and extreme form of the alienation of labor.

Merchant capital had first claim on the surplus of the plantation because merchants supplied credit and material imports, and organized the sale and resale of the sugar in the metropole. The planter had no permanent stake in the colony; his time horizon was short. When times were good and profits were high, he borrowed to expand production, overworked slaves to maximize output, and encumbered estates to relatives in the metropole. When times were bad and profits declined, he mortgaged plantations and consumed assets by overworking his slaves and cutting their rations. The short time horizon of the local business classes engaged in extractive or mineral resources continues to characterize economic development. When times are good, commodity production is expanded and foreign capital is attracted; when times are bad, the real costs of debt service are borne by the population and human and social capital is consumed.

\section{Colonies of Settlement}

In the $18^{\text {th }}$ century, England and France engaged in a contest for exclveist access and control of territory in the Caribbean, India, and North America, resulting in a full-scale war in Euope. The occupation of some prized Caribbean islands changed between these rivals many times. In the era of the Enlightenment and the publication of Adam Smith's The Wealth of Nations in 1776, the tiny island of Granada was eight times more valuable than all of Canada as measured by its exports to Britain. 
The greatest prize however, proved to be the stolen lands of the continent of North America. The establishment of British settlement colonies in New England, and the extension of settlement on lands captured from the Native population in a series of Indian Wars, proved to be a crucial factor in the rise of Anglo-American hegemony.

\section{BRITISH EAST INDIA COMPANY AND FREE TRADE IMPERIALISM IN ASIA}

In $1700,62 \%$ of world output was produced in Asia, compared with $29 \%$ in Europe. As recently as 1820, China's share of world output was 33\% with levels of GDP per capita comparable to levels prevailing in Latin America, the Caribbean, and Eastern Europe. India's share of world production declined precipitously from 1700 to 1820 - with a corresponding drop in GDP per capita - reflecting the destruction of India's industries by the forced importation of British textiles. By 1950, India and China had been reduced to virtual insignificance in the world economy at 4\% and 5\% respectively, and the share of Asia as a whole had declined to 19\%. India's GDP per capita was \$625, while GDP per capita in China had suffered a decline from 1820 -levels to $\$ 450$, below traditional levels of subsistence. It was the advent of industrial capitalism, from its beginnings with the industrial revolution in England in the late $18^{\text {th }}$ century, which created the unprecedented seven-fold increase of productive capacity that projected Europe and North America to hegemony with $66 \%$ of world production in 1950 . By this time, United States GDP per capita was almost twice that of Europe and more than twenty times that of China.

The leading industry of the English industrial revolution was cotton-textiles, and its success depended upon access to overseas markets. The quality was poor and unacceptable in free markets; sales were initially confined to the captive colonial markets of North America, the Caribbean, and most importantly India. 
When the English East India Company first arrived in India early in the $17^{\text {th }}$ century, they were restricted to trading in cotton piece goods because the more profitable spice trade was monopolized by the Dutch. They purchased fine cottons and silks from Indian manufacturers for sale and resale in the metropole. From the mid$18^{\text {th }}$ century, the Company occupied regions of India, including Bengal (now divided into Bangladesh and the Indian state of West Bengal), and waged a successful campaign against the Mogul Empire. As effective rulers of large regions of India, they extracted increasing tribute from peasants and imposed punishing conditions on handloom weavers. From the late $18^{\text {th }}$ century, the rising influence of the Manchester textile industrialists secured prohibitive tariffs on the import of Indian cloth. The East India Company now facilitated the sale of inferior - and with the passage of time ever-cheaperBritish textiles in India. Although the Company lost its monopoly in 1834, it remained enormously profitable and enjoyed great social prestige in England. Malthus, James Mill, and also John Stuart Mill, were lifelong employees of the Company.

In 1858, Britain assumed Imperial rule over the subcontinent and Queen Victoria was crowned Empress of India. Tribute was extracted from the peasantry to finance India's army and the costs of the large network of railways. The economy was reorganized to supply Britain with food (wheat, sugar, tea), and agricultural raw materials of cotton for the textile mills, and jute for making sacks, bags, and sails. Wheat continued to be shipped to London during the famines of the 1870s. The extraordinary refusal to open granaries to feed people starving from famine was justified on the grounds that famine-relief was contrary to the law of the market (Davis, 2000). In British India, industrial development was severely retarded, but the economy was too large and diversified to be transformed into a dependent export economy.

When Britain adopted free trade in the 1840s, she did not relinquish her colonies. In the long reign of Queen Victoria (18371901), Britain acquired most of the rest of her formal and informal Empire, and waged a series of wars from the Crimea to Sudan 
to Afghanistan and beyond (Gallagher and Robinson, 1953). ${ }^{4}$ Victorian England basked in a new prosperity; the middle - and even working - class population had access to a variety of exotic food from the far corners of the world, previously available only to the upper classes. The doctrines of classical economists Smith, Malthus, and Ricardo were reconfigured as neo-classical economics, describing the harmonious outcome of individual decisions in the marketplace. As undisputed premier industrial power, Britain benefited from the free and unrestricted import of food and raw materials. But British prosperity owed as much to its unrivalled naval and military prowess in securing its colonial possessions and opening new markets, as to its industrial superiority.

The British had long encouraged the import of opium to China produced by Indian peasants for the East India Company, where British merchants exchanged it for tea and other high-value goods consigned to Britain. When addiction of China's population became too serious to ignore, the Chinese authorities seized and destroyed large quantities of opium entering their ports. British military intervention (1839-42) resulted in a humiliating Chinese defeat. China was forced to cede Hong Kong and open five treaty ports to British traders, including Canton and Shanghai, where official representatives of the British Crown were installed. Additionally, China was forced to pay heavy war reparations, including restitution for the destroyed opium Opium imports continued. In search of further concessions, Britain initiated the Second Opium War (1856-60) on a flimsy excuse. Joined by France, they attacked and occupied Canton. When treaty negotiations broke down, Britain and France, with 20,000 soldiers and 170 ships, invaded China and ultimately encircled Beijing. China was forced to concede 10 more ports to Western powers; permit foreigners to navigate the Yangtze River and move freely within the interior of China; Britain was

4. In an important revision of British colonial history, Gallagher and Robinson draw attention to the fact that Britain acquired most of her formal and informal empire in the era of British Free Trade before the age of «New Imperialism» and protectionism. 
allowed to take indentured Chinese coolie labor to the Americas; large war reparations were to be paid to Britain and France; and the opium trade was legalized (Beeching, 1975).

The demographic disaster of a population decline of over 50 million people from 1850 to 1870 can be attributed to the human costs of Western incursion, massive opium addiction, and a series of protracted rebellions, and the effective breakdown in government (Maddison, 2006). It presaged the end of the Qing Dynasty, which collapsed in 1912 with the establishment of the Republic of China. The exploitation and humiliation of India and China in the $19^{\text {th }}$ and early $20^{\text {th }}$ centuries gave rise to national movements of independence; India attained independence in 1947, and the communist victory in China in 1949 set that country on the long road to reclaim its historic importance on the Eurasian continent.

\section{FROM BRITISH TO AMERICAN HEGEMONY, 1870-1950}

By 1870, in addition to France, Belgium and Holland, a number of continental European nations had embarked on policies of industrialization, including Austria, Russia, Italy, and -most importantly- Germany. Following the victory of the North over the slave economy of the South, the United States began its rise to industrial supremacy. None of the countries challenging British hegemony adhered to free trade; they protected their infant industries and, in Europe, the state was directly engaged in the provision of economic and social infrastructure, and financial support for industrial development.

The revolution in communications of the telegraph, railways, and steamships with refrigeration facilities, gave rise to a dramatic increase in output and international trade. Over-investment in real estate and stock markets in Europe and the United States precipitated a major financial crisis in 1873 that marked the beginning of the Long Depression that would last until 1896. On the European continent agricultural producers were devastated 
by the arrival of cheap overseas wheat, and industrialists suffered declining profits from intensified competition. The response of European powers to this crisis of overproduction was increased protection of industry and agriculture, and the search for new markets and overseas investment opportunities in Africa and Asia.

At the Berlin Conference of 1884 the vast continent of Africa was assigned to European powers. Ethiopia repulsed Italian attacks to remain the only independent state on the continent. British interest in Africa was as much concerned with the defence of the route to India, their most important and valuable possession, as with the acquisition of new territory. Over the last quarter of the 19 ${ }^{\text {th }}$ century, France and Britain expanded imperial control over Burma, Malaya, Indochina and the Pacific islands. The United States joined European powers in the acquisition of colonies in the Philippines, Hawaii, and the Caribbean.

1900 marked the high point of European power with $47 \%$ of world production. The sun never set on the British Empire because it was said that God did not trust the British in the dark. Imperialism was celebrated as the civilizing mission of the white man's burden. Orientalism was constructed with a view of Asia as stagnant, despotic and backward, and Asians as devious, deceitful, and untrustworthy. The view that white people were genetically superior to other races was accepted as a scientific truth. Concern for the purity of the race and the theory and practice of eugenics was developed in the United States, where the population of European origin shared spaces with peoples of African origin and indigenous peoples whose lands they occupied. The descendants of African slaves were both feared and considered to be existentially inferior.

Although the United States and Germany now challenged British industrial predominance, British industries maintained their overseas markets through highly developed commercial and distributional networks. British hegemony was secured by her unchallenged financial supremacy. The Pound Sterling remained fixed to gold at a value that had not changed from the early $19^{\text {th }}$ century; British gilt-edged securities were as good as gold. 
London was the financial center of the world, and remains so to this day. Britain and France were the leading exporters of capital, while the United States was the recipient of large capital imports, as were Canada and Argentina. A substantial social rentier class, sustained by the backflow of interest from investments in Europe, the Americas, and India, contributed to the literary and cultural achievements of the Belle Époque before the First World War.

British export of capital was predominantly in the form of bonds, generally backed by recipient governments to finance the building of railways, ports, public utilities and other infrastructure, which enhanced the capacity of recipient countries to service their debts in the form of exports of food and raw materials to Britain. Direct investment in mines and plantations was of relatively lesser magnitude. Backflows of interest on investments covered about one-third of British imports until the Second World War.

The complementary character of British investments differed significantly from later exports of capital from the United States, whose foreign investments were principally in the establishment of affiliates and subsidiaries of their transnational corporations. There were few complementarities between US investments in peripheral export economies; the United States was and still is the largest single exporter of agricultural products. While Britain exported portfolio capital and benefited from the return inflow of interest, the US - in recent years - has financed public and private consumption in excess of national production by the import of capital from Japan, China, and other surplus countries principally from the Global South.

In the $19^{\text {th }}$ century, the land-owning classes of the republics of Latin America benefited from strong demand for primary commodities in Europe, Asia, and North America. The income generated from exports sustained industrialisation and urbanisation in the Southern Cone countries. Argentina, in 1900, had a GDP per capita similar to that of Canada, on a level with France and substantially higher than the Mediterranean countries. The Latin American and Caribbean share of world output doubled from 4\% in 1900 to 8\% in 1950, when GDP per capita was higher 
than that of Eastern Europe and only slightly less than that of the Soviet Union.

In African and Asian colonies, labor was exploited in mines and plantations to produce agricultural and mineral exports to industrial centers. In Africa, which was relatively sparsely populated, internal migration of male labor to the regions of mining operations disrupted social organization of village and tribal communities. Plantations and cash-crop exports, established on fertile lands, marginalized subsistence food production. While strong demand for commodity exports increased Africa's share of world production from 3\% in 1900 to $4 \%$ in 1950, with a higher GDP per capita than the average for Asia and twice that of China, Colonial administrations did not permit any form of industrial development.

\section{THE HISTORIC COMPROMISE OF THE FIRST THREE DECADES OF THE POST-WAR PERIOD}

By 1950, two World Wars had impoverished Europe and enriched the United States, whose GDP per capita was unsurpassed. Britain lost the last vestige of her hegemonic power in 1931 when the Pound Sterling was forced to abandon convertibility to gold. By the end of the Second World War, Britain was forced to accept an Anglo-American loan on humiliating terms resembling IMF conditionalities and Keynes suffered defeat at Bretton Woods, but Britain was, aside from Switzerland, still the richest country in Europe.

When the capitalist world emerged from the Second World War, there was a determination to prevent a return to the Depression years of the 1930s. Full employment became the major objective of economic policy and sweeping measures of social security were enacted in Britain and later also in the United States. The historic compromise between capital and labor created a corporate capitalism where the gains of increasing productivity were shared. Real wages and living standards rose, and profits of iconic US corporations producing an array of new consumer goods were reinvested in expanding output and sales. 
Competition between the Superpowers for influence in Africaand, especially, Asia enabled developing countries to engage in strategies of economic planning using an array of fiscal and administrative policy tools to assist domestic industrial development. In the first three decades following the end of the Second World War, Europe, North America and Japan experienced unprecedented rates of growth averaging $4.5 \%$ per annum. The developing world averaged marginally higher growth of 5\% per annum (Patel, 1995); this was a remarkable achievement reflected in rising life expectancy, increased literacy, and the development of national administrative and managerial capacity. The countries of Latin America and the Caribbean, with policies of import-substituting industrialization, achieved average growth rates of 5.5\% and GDP per capita growth of $2.7 \%$ from 1950-8t dDuring this time the large economy of Brazil increased its importance in Latin America from less than a quarter to more than a third, and emerged as a newly industrializing country with levels of industrialization comparable to South Korea. The former colonial countries of Africa experienced average growth of per capita income of 2.4\% from 1950-75. Growth of GDP per capita on the South Asian subcontinent was slower at 1.7\%, but significantly higher at 3.9\% in East Asia. The achievement of these per capita growth rates far surpasses those of Eur.4\% from $1850-1950$, averaging $1.4 \%$ during its century of rise to industrial supremacy, and long-term per capita growth in the United States of 1.8\% (Cardoso and Fishlow, 1992: 197-218).

The fractured decade of the 1970s marked a highpoint in influence of the developing world in the United Nations system. The success of OPEC created illusions of commodity power, the defeat of the United States in the Vietnam War and a series of political revolutions in Asia, Africa and even in Latin America and the Caribbean appeared to mark a turning point in relations of power.

High rates of non-inflationary growth of the real economy of the 1950s and 60s could not be sustained in conditions prevailing in the 1970s; the dissolution of the Bretton Woods financial system in 1973, the OPEC oil shocks, and the combination of rising prices and unemployment made Keynesian macroeconomic policies inoperable. 
Many years of full employment and the introduction of social security systems had strengthened the position of organized labor.

The response to the perception of capitalism in crisis was the neoliberal counter-revolution. The objective of this conscious and deliberate regime change was to raise the profitability of both financial and non-financial corporations by restoring the discipline of capital over labor. Policies were designed in privately funded think-tanks and university research programs, and implemented by Thatcher and Reagan. Measures included a dramatic increase in interest rates for the benefit of institutional creditors; deregulation to facilitate corporate mergers and acquisitions; drastic reduction of corporate and income taxation; imposition of regressive sales tax; privatization of state assets; attack on trade union power; application of capitalist criteria of cost-effectiveness to social infrastructure of education and health; and liberalization of trade and cross-border capital flows. These policy measures were accompanied by an ideological counter-revolution in prevailing economic doctrine. Belief in the efficiency of market signals to guide the economy was restored to the position it enjoyed in the 1920s before the Great Depression.

Development economics was rejected as excessively interventionist. The blunt instrument of monetary policy was employed to close balance of payments gaps by compressing private and public expenditure. Structural Adjustment Programs designed by International Financial Institutions oriented toward outwardlooking development disadvantaged exporters of primary products because technological change and competition from synthetics had weakened demand. In open export economies, devaluation of the currency had the distributional effect of favoring capital engaged in export industries while reducing the real wages of labor because imports become more expensive. Together with the removal of subsides to essential food and agricultural inputs, the working population of economies dependent on primary products were impoverished. East Asian and other developing countries engaged in export manufacturing were better positioned to benefit from the liberalization of international trade. 


\section{DIVERGENT DEVELOPMENT EXPERIENCES OF LATIN AMERICA, AFRICA, AND ASIA: 1980-2006}

The shock of a drastic rise in interest rates in the US, the stronger dollar, and weaker external markets due to the recession in the United States precipitated the Latin American debt crisis. per capita income fell by $8 \%$ in the lost decade of the 1980s. Only Brazil maintained continuous positive GDP growth, averaging $2.7 \%$. In some Latin American countries GDP per capita levels in 1990 fell below those prevailing in 1960 (Cardoso and Fishlow, 1992: 197-218). IMF interventions rescued over-exposed commercial banks. The entire burden of excessive lending was borne by the populations of the debtor countries. The World Bank ascribed responsibility for the collapse of growth in the 1980s to policy errors by governments that had departed from following market signals and practiced excessive state intervention and import substituting industrialization policies. In the 1990s Latin American technocrats, trained in US graduate schools, instituted policies according to the Washington Consensus. Although growth averaged $3.4 \%$ in the 90s (World Bank, 2005), income disparities widened and poverty increased, resulting in the election of a new generation of left-leaning politicians more responsive to popular discontent than to doctrines of neo-classical economics.

Too poor to have attracted commercial bank loans, the countries of Sub-Saharan Africa were indebted almost exclusively to multilateral agencies and bilateral donors. The great majority of Structural Adjustment Programs were imposed on SubSaharan Africa and the budgets of indebted countries were effectively written by the International Financial Institutions. In striking contrast with positive annual per capita income growth from 1950-1975, per capita income failed to grow from 1980 to 2000. Average annual GDP growth was only 1.7\% from 1980-90, somewhat stronger at 2.4\% over the next decade, from 1990-99 (ibid), and average GDP per capita from 1985 to 1995 was negative at minus 1.1\% (World Bank, 2004). The number of poor almost 
doubled, from 200 million in 1981 to 380 million in 2005, and the poverty rate, at $50 \%$, was unchanged over the same period (Ravallion and Chen, 2008).

Whereas Latin America and Africa stagnated in the 1980s, and Africa failed to make a significant recovery in the 1990s, the larger but poorer regions of South and East Asia continued on a high growth path. While the primary commodity exporting countries were engaged in interminable but fruitless negotiations for a new international economic order, the four little Tigers took advantage of strong growth in international trade to encourage export manufacturing. The rise of the entrepot economies of Singapore and Hong Kong, and Korea and Taiwan, both former colonies of Japan, defied prevailing expectations of failure among Western development experts Left and Right. The Left ascribed the success to assistance provided by the US to its client states, the Right ascribed it to the adoption of outward-oriented laissezfaire policies. While it is true that geopolitical considerations privileged Japan and the Tigers in access to US markets and finance, the extraordinary rise of Korea and other East Asian Tiger economies from dirt poor to levels of GDP per capita approximating or surpassing those of Europe in just 30 years cannot be ascribed to favorable external circumstances and certainly not to noninterventionist laissez-faire policies.

Korea had embarked on industrial policies, which combined import substitution with export promotion guided by large and effective planning agencies, with the full support and direct participation of political authorities since the late 1960s. The corporatist business organization of Korea was modeled on Japan, with close association between large productive enterprise and domestic banks. Foreign direct investment (FDI) was restricted. In Taiwan, medium-sized enterprises were favored. The Tigers were in the first tier of a flying-geese formation headed by Japan, with the ASEAN countries in the next tier thus forming dense networks of vertical and horizontal trade and investment throughout East Asia and mainland China. With variations regarding relations 
with multinational corporations and banks, they also practiced combinations of domestic industrialization with the export of manufactures. In all these cases, nationally owned enterprises were critical to successful economic development (Amsden, 2007). The forced march to high growth was achieved by high rates of savings and domestic investment, long hours of work, and authoritarian governments driven by a national project to overcome the stigma of backwardness and inferiority to former colonial powers, whether Japanese or British - in the case of Malaysia.

Capital account liberalization and large outflows of foreign capital precipitated the Asian Crisis of 1997. Assistance from Japan was offered but overruled by IMF intervention, which aggravated the crisis by permitting local banks to fail and bankrupting viable businesses for lack of credit. Some currencies fell by as much as $75 \%$ and savings were wiped out. Assets of local corporations were purchased by foreign capital at fire-sale prices and remaining restrictions on foreign investment were extinguished. Only Malaysia, whose foreign debts were covered by reserves, stemmed the tide of impoverishment by declaring a moratorium on remittance of profits and capital flight. Western commentators now dismissed the Asian 'miracle' as 'crony capitalism', and the IMF continued to advocate capital account liberalization. The lessons of vulnerability to speculative attacks were not lost on East Asian exporters of manufactures; they accumulated reserves and negotiated mutually supported regional arrangements of currency swaps. Although domestic investment declined during the Asian crisis, the weakened economies of the ASEAN region resumed strong economic growth in the 2000s, assisted by strong growth in China and buoyant demand in the United States and Europe.

In the late 1970s, China launched a program of economic reform combining private with state enterprise in a unique model that cannot be described as either capitalist or socialist, but has features of both. It has yielded unprecedented high rates of growth, based on compression of consumption by very high rates of domestic investment and strong export growth. Markets for manufactured exports in North America and Europe were complemented by a dense 
network of Sino-centered regional trade and investment. Domestic savings and investment rose slowly from levels of 20\% of GDP in 1980 to an average of $25 \%$ by the end of the 1980s; China attracted almost no foreign investment in this period (Tang et al., 2008).

In the early 1990s China relaxed regulations to encourage foreign investment, which reached 6\% of GDP in 1994 and declined progressively to $4 \%$ in 2003 , by which time domestic investment had increased to the extraordinary level of $48 \%$ of GDP. FDI as a percentage of gross capital formation averaged $12 \%$ in the $1990 \mathrm{~s}$, declining to $6 \%$ by 2008 (UNCTAD, 2009). These figures would indicate, and an econometric study has confirmed, that domestic and foreign investment in China have been complementary in their contribution to economic growth. FDI has not crowded out domestic investment, which clearly remains the principal driver of economic growth, but has played an important role in access to foreign technology and markets. Some 90 of China's 200 largest exporters are affiliates of multi-national corporations. Hong Kong is the principal entry point of FDI, constituting nearly 60\% in 2009. Other sources of FDI in order of descending importance are: Taiwan 7\%; Japan 4.5\%; Singapore 4\%; United States 4\%; South Korea 3\%; Great Britain 1.5\%; Germany 1\% (Blanchard, 2007: 67-102).

Building on the infrastructure, literacy and educational attainments of the Mao-era, Deng Xiaoping's change of course launched an industrial revolution greatly surpassing both the scale and the speed of that of Western Europe two hundred years earlier. There has been a shift of labor from agriculture to industry on a huge scale, with enormous social dislocation, growing inequality, and environmental degradation. But thirty years of high economic growth of $10 \%$ per annum reduced poverty from $53 \%$ of the population to $4 \%$, lifting more than 600 million people out of poverty according to the World Bank (Ravallion and Chen, 2008).

The economic development strategy adopted by India differed in important respects from that of East Asia or China. As a large country of diverse religious and ethnic communities, and many languages, the founding Nehru development model of postindependence India was based on secular values of coexistence 
and tolerance in a mixed economy combining private business with public enterprise and state planning. The objectives of early development plans were influenced by Soviet industrialization, with emphasis on basic industry and production for the domestic market. India did not engage in export manufacturing. Economic growth was modest and income disparities increased over the first forty years. Liberalization policies in the 1990s increased growth rates somewhat from $5.8 \%$ in the 1980 s to $6.1 \%$ in the 1990 s, and attained extraordinary levels of 8-9\% growth from 2003 to 2007 (World Bank, 2004). Disparities widened further as three decades of high growth gave rise to a new middle class of some 300 million people. For the majority of the population however, growth was more like $2 \%$ per annum; and for some, none at all. The percentage of people living in poverty declined from $60 \%$ to $42 \%$ from 1980 to 2005 , the number of poor increased from 421 million to 456 million; of the world's 1.4 billion poor, one-third are found in India, more than in Sub-Saharan Africa (Ravallion and Chen, 2008).

\section{DIVERGENT PER CAPITA INCOME}

A comparison of GDP per capita in 1950, 1980, and 2006 as a percentage of prevailing US levels reveals the striking difference in the period from 1950 to 1980, when Latin America, Africa, and Asia all experienced steady growth, and the period from 1980 to 2006. In the latter, Latin America, the Caribbean and Africa fell into a deep debt trap and became dependent on official capital flows with attendant neoliberal conditionalities. This contrasts with more autonomous sources of strong economic growth in East, South and Southeast Asia.

From 1950 to 1980, the majority of Latin American and Caribbean countries experienced per capita income growth equaling or surpassing that of the United States; this was an extraordinary achievement considering significantly higher population growth in Latin America and the Caribbean. The effects of the debt crisis are evident in the relative decline of Latin American and Caribbean per 
capita income as a percentage of US GDP per capita, from levels of $29 \%$ in 1980 to $21 \%$ in 2006 . Considering rapid population growth, Africa almost maintained its per capita position relative to the US due to strong GDP growth from 1950 to 1980 . By contrast, per capita income relative to the US declined from 8\% in 1980 to $5 \%$ in $2006 .{ }^{5}$

We note the rapid rise of Japan, from $20 \%$ of US per capita in 1950 to $72 \%$ in 1980, maintaining its relative position to 2006 . Following Japan, the poor countries of Korea and Taiwan, with $9 \%$ and $10 \%$ in 1950 , ascended to attain $22 \%$ and $32 \%$ in 1980 , with continued relative per capita income growth to levels of $58 \%$ and $63 \%$ respectively in 2006 . The richer entrepot economies of Singapore and Hong Kong, with $23 \%$ in 1950, attained levels of $84 \%$ and $95 \%$ of US per capita income respectively by 2006; GDP per capita in Singapore exceeded that of Britain and many Western European countries, Hong Kong likewise. GDP per capita in South Korea and Taiwan is at the level of Mediterranean Europe. Indonesia and Thailand, illustrative of the ASEAN group which formed the second tier of the flying geese, both very poor at 9\% of US GDP per capita in 1950, rose to only $10 \%$ and $14 \%$ in $1980 \mathrm{~h}$ accelerating growth to attain $13 \%$ and $27 \%$ respectively in 2006; this places Thailand above Eastern Europe and Mexico.

The rise of East Asia, led by the emergence of Japan as a major economic power, followed by the relatively smaller economies of the Four Tigers and subsequently by the less spectacular growth of the more important group of ASEAN countries, was sealed by the spectacular high growth of China's economy. Starting in 1950, with a per capita income of $\$ 450$, equal to $5 \%$ that of the US, initially growing slowly but rising to $6 \%$ of US levels by 1980 , China's high growth path attained per capita levels of $20 \%$ relative to the US in 2006. China's share of world production increased from $5 \%$ in 1950 to $17 \%$ in 2006, now almost three times that of Japan at $6 \%$ in PPP- and since August 2010 equal in current dollars.

5. The figures for Africa reflect the continent in its entirety, including Northern Africa and South Africa. 
India experienced modest growth to 1980; per capita income relative to the US declined from $7 \%$ in 1950 to $5 \%$, but accelerating high growth from 1980 to 2006 lifted India's GDP per capita to 9\% of US levels, and her share of world production doubled to $6 \%$. In 2006, East and South Asia accounted for a 38\% share of world production, equalling that of the combination of Western Europe (18\%) and the United States (20\%), a historic shift from 1950, when East and South Asia's share of world production was only $16 \%$ and that of Western Europe and the United States was 53\%.

The dramatic difference in development paths of the countries and regions of East Asia on one hand, and Latin America and Africa on the other, invites explanation. History may assist us in understanding why it was possible for Japan and subsequently the Tiger Economies of Southeast and Northeast Asia, and most importantly China and also India, to mobilize national resources to engage in the slow return to the position Asia occupied in the world economy prior to the industrial revolution.

Asia was attractive to European traders and imperial powers because the high quality of their products offered opportunities for gains from trade, captive markets for manufactured exports, cheap labor for mines and plantations, and economic tribute in the form of taxes and interest on loans - secured by colonial occupation- but the Europeans did not destroy indigenous social institutions; they did not impose their religion, they did not establish settlements. Although they forced China to open its ports to European commerce, engaged in wars, and extracted tribute, China retained its political independence. Japan closed its ports to Europe for 200 years to protect its sovereignty and rose to become an Imperial power. Notwithstanding the economic exploitation of colonial possessions, the traditional cultural and historical heritage of Asia survived and nourished the aspirations of business and professional classes to national independence.

The legacies of the westward expansion of Europe to create an Atlantic overseas economy embracing all of the Americas, the Caribbean, and Western, Central and Southern Africa were 
profoundly different from the impact of European commercial expansion and political colonialism in Asia. The peoples and civilizations of the Atlantic Economy were the first to be uprooted and transformed into peripheries serving the economic interests of European metropoles. In the Americas, European conquest and settlement dispossessed and marginalized indigenous populations and Christianity was imposed. Many indigenous languages have vanished; the official language of all American and Caribbean countries is one or another European language. Economic and political elites of Latin America have more affinity with the metropoles than with subordinate classes of peoples of Amerindian or African origin, although there was a greater sense of national identity in Brazil. Cleavages of ethnicity and class have resulted in extreme income inequalities. This heritage of European expansion in the Mercantilist era has been an acknowledged handicap of the richer, but endemically unstable countries of Latin America and the Caribbean, in relation to the poorer, but socially more cohesive national economies of Asia.

Two centuries of the slave trade de-populated and destabilized Africa, and in the $19^{\text {th }}$ century, colonialism imposed dysfunctional political structures which burden the continent to this day. European settlement in East Africa, but most importantly in South and Southern Africa, has exacerbated civil conflict and remains a major challenge to inclusive economic development.

The economies of Latin America, the Caribbean, and also Africa, were transformed into agricultural and mineral raw material exporters to industrial centers. It was in the «Western» regions of the Non-European world that theories of dependency were developed and it is to these regions that they are primarily applicable. We recall that the center-periphery terminology originated with the celebrated Prebisch Manifesto.

Asian countries have maintained a greater degree of autonomy and are today better placed to adjust to the diminishing need of the industrial countries for primary products than the Latin American, Caribbean and African peripheries whose economies largely 
remain dependent on their export. Since independence in the early $19^{\text {th }}$ century, landed Latin American oligarchies have benefited from the export of temperate and tropical commodities. Although there has been significant industrialization in the Southern Cone of the continent and Brazil is emerging as an industrial powerhouse, 17 Latin American and Caribbean countries are still dependent on three or fewer commodities for over $50 \%$ of their total exports; and7seven countries are dependent on the export of a single commodity. In Africa, the decolonization of the 1950s and 60s did not diminish commodity export dependency — currently, 34 African countries depend on three or fewer commodities for over $50 \%$ of their total exports - and 23 countries are dependent on the export of a single commodity. This contrasts with the situation in East and South Asia where only6 six countries depend on three or fewer commodity exports, and only 2 two depend on a single commodity. ${ }^{6}$

It is not by accident that the great majority of IMF and World Bank stabilization and adjustment programs were found in the countries of Latin America, the Caribbean, and Africa, and few of the countries of Asia came under similar neo-colonial tutelage. Thus of 50 structural adjustment loans in the 1980s, 32 were extended to Sub-Saharan Africa; 12 to Latin America and the Caribbean; 3 to Asia; 2 to North Africa; and one to Europe (Ali, 2004). It is hardly surprising that the World Development Report of 1992 stated that, «The experience of other developing regions has been markedly different from that of Asia. All poverty measures worsened in sub-Saharan Africa, the Middle East and North Africa and Latin America and the Caribbean» (World Bank, 1992: 42). A more recent World Bank study concluded that, «marked regional differences in progress against poverty persist. Poverty in East Asia has fallen from nearly 80 percent of the population living below US $\$ 1.25$ a day in 1981 to 18 percent in 2005. However, the poverty rate in Sub-Saharan Africa remains at 50 percent in 2005- no lower than in 1981, although with more encouraging recent signs of progress» (Ravallion and Chen, 2008).

6. Common Fund for Commodities; Basic Facts; May 2005. 
In the opening decade of the $21^{\text {st }}$ century, strong commodity prices for food, petroleum and mineral exports enabled a number of countries in Latin America, the Caribbean, and Africa to pay down debt to the IMF, thereby reducing its income from interest. On the eve of the Financial Crisis the IMF was running an operational deficit and contemplating a reduction in staff.

\section{SHIFTING POWER RELATIONS FROM THE WEST TO THE REST: IMPACT OF THE 2008 FINANCIAL CRISIS ON THE GLOBAL SOUTH}

The Financial Crisis of 2008 was the inevitable outcome of the liberalization of global capital starting with the demise of the Bretton Woods order in 1973. Capital was progressively freed from discipline and oversight. Productivity increases accrued to upper-income groups and inequality levels in the US reached levels not seen since 1929. Real median wages and salaries did not increase in the thirty years from 1980. In the years preceding the crisis, finance, insurance, and real estate accounted for more than 20\% of GDP in the US, rising from $15 \%$ in 1971, while manufacturing declined to $12 \%$ from $23 \%$. The hollowing out of manufacturing was even more severe in Britain where it declined from $32 \%$ to $11 \%$ in the same period. Consumption expenditures have been sustained by everexpanding debt while gross fixed capital formation as a percentage of GDP has been in secular decline in industrialized countries.

A neoliberal model of corporate governance of maximizing shareholder value replaced earlier practices of maximizing market share and long-term profitability. From the mid-1980s to 2000, the share of financial corporations in total corporate profits increased from $16 \%$ to $40 \%$ in the US. This is a predatory form of capitalism operating on a short time horizon, achieving higher returns by drawing capital out of productive enterprise, and profiting by manipulating markets and devising financial innovations, whereby the stock market becomes a casino rather than a guide to the longterm prospects of non-financial corporations. The Asian Crisis of 
1997 might have served as a warning, but United States authorities lifted remaining constraints on financial liberalization in 1998 by permitting the consolidation of commercial and investment banking. Rising stock markets and real estate values were sustained and encouraged by easy credit available from central banks. Financialization assumed unimaginable proportions; the estimated value of total derivatives in 2007 was $\$ 600$ trillion, according to the United Nations' $964 \%$ of world GDP.

The immediate source of the Financial Crisis of 2008 was the United States, but the transmission of the crisis was through London, the principal financial center for international transactions. Political, economic and financial links between the US and the UK are close; it is no accident that Britain has been the closest ally of the United States in the wars in Iraq and Afghanistan. In the US and Britain public and private national expenditure in excess of national output could not have been sustained without ever-increasing capital inflows. In the ten years from 1997 to 2006, the US current account deficit increased from 1.7\% of GDP to 6.2\%; in Britain, over the same period, it increased from $0.1 \%$ of GDP to $3.9 \%$. With the exception of Spain, the United States and Great Britain were the world's largest recipients of international capital flows in the runup to the crisis. The United States and Britain are now the world's largest debtor countries. The US, the largest source of capital exports in the Bretton Woods era, is now the world's largest debtor country, $\$ 13.8$ trillion, or $95 \%$ of its GDP. While Britain, the previous hegemonic power of the long $19^{\text {th }}$ century, has accumulated an external debt of US, $\$ 9.4$ trillion, or 397\% of its GDP. ${ }^{7}$ Some other European countries with very high debt ratios may be dangerously exposed to speculative attacks on their bonds or currencies.

The countries most severely affected by the Financial Crisis were those most closely integrated into capitalist circuits of finance

7. Inter-Agency Group on Economic and Financial Statistics; Quarter 4, 2009. Interestingly, debt ratios for large developing countries of Korea 41\%; Turkey 40\%; Argentina 37\%; Indonesia 28\%; South Africa 24\%; Mexico 20\%; India 17\%; Brazil $14 \%$; and also Japan $40 \%$, are very much lower. 
and trade - in the first instance all of Europe from Scandinavia to the Mediterranean and Ireland and Britain to Ukraine and Russia; the United States and its southern peripheries of Mexico, Central America and the Caribbean; Japan and the financial centers of Singapore and Hong Kong; and South Africa. The scale of the 2008 Financial Crisis could not be handled by the G8 alone; all its members were severely affected and their banks dangerously exposed, particularly in Eastern and Central Europe. The G20, established in the aftermath of the Asian Crisis and including the world's major surplus countries of the Global South (China, Saudi Arabia, Indonesia, Korea, Argentina and Brazil), was convened. It authorized an increase in the resources of the IMF by $\$ 500$ billion and an allocation of $\$ 250$ billion worth of Special Drawing Rights, as well as an additional commitment of funds for a total of $\$ 1.1$ trillion. IMF programs for close to 100 billion dollars were extended to the countries of Central and Eastern Europe to prevent default on loans denominated in Euros, Swiss Francs, Pound Sterling, and US Dollars. Aside from a large line of credit extended to Mexico and smaller programs in Central America and the Caribbean, no other countries of the Global South required IMF assistance, with the exception of programs in Pakistan, Sri Lanka, and Iraq - in all three cases the consequences of wars and unrelated to the Financial Crisis.

Contrary to predictions, and with few exceptions, the countries of the Global South maintained positive (although reduced) rates of growth. China and India maintained a high growth path and a number of large Asian countries recorded robust growth in the crisis year of 2009, including Indonesia, Bangladesh, and Vietnam. Importantly - and with almost no exceptions - all the countries of Asia were in surplus on external accounts. In addition to China and Japan, the countries of East and Southeast Asia contributed a substantial surplus to balance the deficits of the United States and Eastern Europe. The three largest countries of Africa (Nigeria, Ethiopia, Egypt) maintained strong growth; very few countries on the continent dipped into negative growth. By contrast, the countries of Latin America and the Caribbean, more closely integrated with 
the capitalist western heartlands, were more severely affected by the crisis. Mexico, vulnerable through NAFTA, took a very big hit. Otherwise, in continental Latin America, growth stalled at a little above or below zero (including Brazil) while many of the tourismdependent countries of the Caribbean recorded negative growth. Many countries were in deficit, while others were in surplus including the oil exporters of Venezuela and Trinidad, as well as Argentina and Bolivia.

It was widely expected that the Financial Crisis and the consequent recession in the major capitalist countries would be transmitted to the Global South by declining export earnings, FDI, remittances, and tourism, and that it would be poor people in poor countries that would be most seriously affected. What actually happened illustrates the degree to which traditional relations of trade and finance between capitalist centers and the Global South are undergoing an historic change. Developing countries are not as dependent on exports to North America, Europe, and Japan as they were in earlier times. From 1995 to 2005, the share of their exports to developed countries declined from $56 \%$ to $48 \%$, while their share to other developing countries increased from $40 \%$ to $45 \%$ - a three-fold increase in volume (UNCTAD, 2008).

Perhaps the most dramatic change in the North-South relationship is the dependence of the North on net capital exports from the South. On the eve of the crisis, in 2007, developing countries as a whole received net private inflows of $\$ 325$ billion and remitted to official agencies a net outflow of $\$ 129$ billion, for private and public net inflows of $\$ 196$ billion. Accumulated reserves of $\$ 919$ billion however, invested in US and other government securities amounted to an overall export of capital of $\$ 723$ billion. With regional variations, «developing countries as a group have attained independence from international capital markets in the new century» (ibid).

The balance of payments deficits of the United States, increasing from approximately $\$ 100$ billion in 1995 to over $\$ 700$ billion in 2007, together with the deficits of Central and Eastern Europe 
of $\$ 130$ billion, were covered by the surpluses of oil exporters, China, Japan, and a number of Asian countries, while the Eurozone was roughly in balance. Experience of costly exchange rate and financial crises in the 1990s encouraged central banks of middleincome and also poorer developing countries to accumulate reserves (invested at low yields of interest in securities) as a precaution against speculative attacks on their currencies. The precautionary surpluses are very large and represent a sacrifice of resources that could otherwise have been used for public and private consumption.

According to UNCTAD, accumulation of surpluses together with rates of domestic investment higher than at any time in the last thirty years attest to the capacity of countries with relatively low GDP per capita to mobilize national resources and attain a high rate of gross capital formation, which is the basis for sustainable long-term growth. Foreign investment may be useful in access to technology and markets, but contrary to conventional wisdom, developing countries are not potentially short of savings per se. «This fact challenges orthodox development theory. It implies a need for a rethinking of the most crucial assumptions about the functional relation between savings, investment, capital flows (including both FDI and official development assistance) and the alternate policies and paths for catching up» (ibid).

\section{CONCLUSION}

In this text, we have used Maddison's estimates of GDP and GDP per capita in international purchasing power in 1990 Geary-Khamis dollars. All estimates involve some guesswork, but these are the best available and are generally accepted. International comparisons of GDP per capita can only meaningfully be made by adjusting GDP for domestic purchasing power. The regional distribution of world GDP by this measure differs from results obtained by simply converting GDP in local currencies by the dollar exchange 
rate. PPP yields higher relative GDP for large developing countries where prices prevailing in the domestic economy are lower than world prices generated in world markets. The more common comparison of GDP in current US dollars, which yields lower relative GDP for large developing countries, reflects a lower degree of commercialization of a domestic economy. This measurement underestimates economic development in terms of the real capacity of countries to meet domestic requirements of consumption and capital formation, and exaggerates differences of GDP per capita. Thus for example, the relative importance of the four BRIC countries (Brazil, Russia, India, China) in the world economy in 2006 in PPP, was $28 \%$, of which China $17 \%$ and India $6 \%$, while in current US dollars, the BRIC share was only $11.5 \%$, of which China $5.4 \%$ and India 1.9\%; the relative importance of the US in PPP was $20 \%$, which rose to $27 \%$ in current dollars.

It can be said that the relative shift of world production from North and West to South and East based on PPP has exaggerated the importance of the Global South in the world economy. Yes, in a way it has. Yet it is evident that China and India (with a mere $7 \%$ of world output in current US dollars) together with other regions of the Global South, sustained world growth when the Western heartlands of capitalism suffered the worst economic crisis since the 1930s. It is also evident that the major countries of the Global South were more resilient to declining export markets, remittances, and FDI flows than was expected by the international financial institutions.

The crisis however, has accelerated the concentration of financial and economic power in ever fewer and larger transnational corporations. If we view the world as dominated by the concentration of financial wealth, multinational corporate power, and military might, the Global South appears more dependent than ever on access to rich markets, foreign investment, and overseas development assistance by public (and increasingly private) agencies; it remains cursed by corrupt governments and greedy elites; mired in poverty, disease, and conflict; and the source of unwanted migration. 
The gross inequality of economic power is undeniable, but so is the fact that the financial crisis has proven that the AngloAmerican style of capitalism, with its emphasis on short-term financial gain accompanied by de-industrialization, is widely discredited, and that the Global South as a whole is cutting loose from traditional dependence on the West. Arthur Lewis said a long time ago that the developing world has within it all the resources required for economic development, but now there are also many millions of young people with tertiary education and many millions more with access to communication and information technology to fashion worlds based on different values.

The capitalism that we know was born in the explosive expansion of commerce and conquest by the young nation-states of Atlantic Europe in historically specific circumstances. It gave rise to industrial civilization, urbanization, and many wonderful scientific and technological achievements. But the instrumental rationality of the West has now depleted natural resources beyond the limits of sustainability and has fashioned an economic system that requires endless accumulation. Financialization has been a means of sustaining profitability of capital in saturated consumer markets through a sophisticated redistribution of wealth to the privileged classes. Capitalism has reverted to its origins in commerce and conquest; financial bondage, the creation of rents by corporate capital, dispossession of land, plunder of natural resources, and even plantations - now for biomass to be used as fuel.

The Financial Crisis is not the end of capitalism, but is a spatial shift from North and West to South and East. Money capital is global, it has no fixed address, and globalization has given the impression of uniformity of aspirations to Western consumer society. Societies however, are diverse and it is the society that ultimately sustains the economy. The roots of development are not to be found in access to markets or capital but in the abilities of governments to mobilize national resources and develop institutional capacity to release popular creativity. Real wealth is in the real economy- in natural resources and the labor and 
ingenuity of its people - and the greater part of the real wealth of the world is in the Global South. All modern economies are mixed economies combining public enterprise, private business, non-profit activity, small-scale and self-employment, diverse forms of social or cooperative associations, and work done within the household. The economic, social, and political institutions of capitalist Europe, the United States, and Japan are very different from each other; there is scope for the creation and innovation of new economic and political institutions conforming with the specific characteristics and requirements of the diverse regions of the Global South. By enlarging the canvas of development to embrace the diverse societies and civilizations of the nonEuropean world, we open the possibilities of not just another world, but many other worlds. We live on one planet but the solution to the civilizational problems that confront us here require the accumulated popular knowledge and wisdom of all the peoples that inhabit it.

\section{REFERENCES}

Ali, Abdel Gadir Ali (2004). Structural Adjustment Programs and Poverty in Sub-Saharan Africa: 1985-1995, in http://www.idrc.ca/en/ev56338-201-1-DO_TOPIC.html.

AMSDEn, Alice (2007), Escape from Empire: The Developing World's Journey through Heaven and Hell, Cambridge, MIT Press.

ARRIGHI, Giovanni (1994), The Long Twentieth Century: Money, Power, and the Origins of Our Times, London, Verso.

BeEching, Jack (1975), The Chinese Opium War, New York, Harcourt Trade Publishers.

CARDoso, Eliana and Albert Fishlow (1992), «Latin American Economic Development: 1950-1980» in Journal of Latin American Studies, Quincentenary Supplement: The Colonial and Post Colonial Experience. Five Centuries of Spanish and Portuguese America, vol. 24, pp. 197-218, http://www.jstor.org/pss/156952 
Davis, Mike (2000), Late Victorian Holocausts: El Niño Famines and the Making of the Third World, London, Verso.

Furtado, Celso (1983), Accumulation and Development: The Logic of Industrial Civilization, Oxford, Martin Robertson.

GALLAGHER, John and Ronald Robinson (1953), «The Imperialism of Free Trade» in The Economic History Review, Second series, vol. VI, no. 1.

InTER-Agency Group on Economic and Financial Statistics (2009), Quarter 4, http://www.principalglobalindicators.org.

LevitT, Kari (1970; 2005), Silent Surrender: The Multinational Corporation in Canada, Montreal, McGill-Queen's University Press, in http:// mqup.mcgill.ca/book.php?bookid=1280

MAdDISon, Angus (2006), The World Economy, Paris, OECD Publishing.

MACKAY, Charles (1841; 1980), Memoirs of Extraordinary Popular Delusions and the Madness of Crowds, New York, Harmony Books.

Patel, Surendra (1995), Technological Transformation in the Third World: Volume V: The Historic Process, Helsinki, UNU-WIDER.

Ravallion, Martin and Shaohua Chen (2008), «The developing world is poorer than we thought but no less successful in the fight against poverty», World Bank, in http://www.worldbank.org.in/WBSITE/EXTERNAL/COUNTRIES/SOUTHASIAEXT/INDIAEXTN/0,,contentMDK:21880 805 pagePK:141137 piPK:141127 theSitePK:295584,00.html.

UNCTAD (2008), Development and Globalization: Facts and Figures, New York, United Nations, in http://www.unctad.org/en/docs/gdscsir20071_en.pdf.

WorLD Bank (1992), World Development Report, Washington, WB (2004), Beyond Economic Growth: An Introduction to Sustainable Development (second edition). 
